\title{
Ranking factors affecting the quality of banking services using analytic network process
}

\author{
Hooman Pourmohammad", Mostafa Zandieh and Hasan Farsijani
}

Faculty of Management and Accounting, Department of Industrial Management, Shahid Beheshti University, G.C., Tehran, Iran

\begin{tabular}{l}
\hline C H R O N I C L E \\
\hline Article history: \\
Received October 25, 2015 \\
Received in revised format: \\
March 28, 2016 \\
Accepted June 3, 2016 \\
Available online \\
June 42016 \\
\hline Keywords: \\
Analytic network process \\
Quality of banking services \\
Retail banking \\
Bank agility \\
Quality of service
\end{tabular}
A B S T R A C T

\begin{abstract}
This paper seeks to identify the priority of factors affecting the quality of banking services in Bank Saderat Iran for better allocation of resources to enhance the quality of its banking services. The study develops a fuzzy method to handle uncertainty associated with the data and using analytical network process (ANP) ranks different factors influencing on service quality. The results have indicated that the quality of e-services (ESQ) is the most important factor followed by the quality of banking services agility (ASQ), the service system quality (SSQ), and the behavioral service qualities (BSQ). Moreover, the employees' competence and skills, the reliability of the electronic system and the reliability of the service system, an impeccability banking system integrity and accountability instruments are among other effective factors influencing on the quality of banking services.
\end{abstract}

(c) 2016 Growing Science Ltd. All rights reserved.

\section{Introduction}

Service quality is an important perspective of any service provider especially in banking industry and the role of service quality has been essential for the success of these organizations (Prasad \& Kumar Jha, 2013). With an increased competition in banking services, service quality has received significant attention. Aneesh et al. (2014) developed an integrated approach to measure service quality and provided guidlines for the development of innovative service by identifying weak attributes which are critical for customers. Cheserek et al. (2015) presented an effective method for measuring the effect of quality financial services on customer satisfaction by commercial banks in Kenya using SERVQUAL technique (Parasuraman et al., 1998; Sureshchandar et al., 2002). They reported that reliability, responsiveness, assurance and empathy could substantially and positively influence on customer behaviors in terms of satisfaction, but tangibility had no significant influence on satisfaction level of customers. Dehaghi et al. (2014) evaluated the effect of individual factors for the implementation of agility strategy (Shaarabh et al., 2014) in municipality organization. They reported that employee professionalism, organizational commitment and job motivation were among the most important factors promoting agile strategy.

* Corresponding author.

E-mail address: pourmohammad hooman@yahoo.com (H. Pourmohammad)

(C) 2016 Growing Science Ltd. All rights reserved. doi: $10.5267 /$ j.ds1.2016.6.001 
Gunarathne (2014) in an empirical investigation detected a positive and meaningful relationship between customer satisfaction and serice quality. According to Igaz and Ali (2013), service quality is a reflection of organizational performance as an ultimate measure of customers satisfaction especially in the service industry, which could yield customers retention. Jahanshani et al. (2014) investigated the relationship between customer service and product quality with customer satisfaction and loyalty in the context of the Indian automotive industry. They reported that there were some positive correlations between the constructs of costumer service and product quality with costumer satisfaction and loyalty. Kaur and Kiran (2015) tried to find out how the e-banking influenced on banks' operations in the Indian banking sector. The study detected the factors to be either improved or enhanced and the banks could concentrate on the areas they wish to improve/ enhance for reaching better customer loyalty.

Kazemi and Amini (2013) performed an empirical investigation to determine the factors influencing on customer satisfaction in Bank Maskan (Housing Bank) branches in Mashhad province of Iran based on service quality and prioritizing three categories of must-be, one-dimensional and attractive requirements. The study showed that the least time standing in line counter and the emotional relationship with bank employee had maintained the maximum and minimum impacts on customer satisfaction, respectively. Further analysis also indicated that non-availability of some others facilities such as water cooler and chair maintained the most and the emotional relationship with bank employee maintained the least effect on customer dissatisfaction. Munir and Rahman (2015) investigated the relationship between e-banking service quality and customer satisfaction in Bangladesh. They found a relationship among service quality, information quality and system quality and customer satisfaction.

Nikzat et al. (2014) investigated the relationship between service quality on one side and customer satisfaction and loyalty on the other side and reported that the portion of different service quality dimensions was almost equal among different factors. Sakhaei et al. (2014) performed an empirical investigation on service quality indexes in Internet Banking in order to understand the effect of service quality factors of Internet Banking on customer satisfaction in Iran. The study indicated that the 6 service quality dimensions maintained positive relationships with customer satisfaction in Internet Banking. Sanadgol (2014) studied the relationship between school organizational agility and principals' job satisfaction and found a substantial relationship between principals' gender and their job satisfactions. Sazesh and Siadat (2015) found a positive relationship between the quantum management and organizational agility except quantum sense in transportation industry.

Seyedhosseini and Keyghobadi (2014) developed an integrated technique for developing mechatronic products within the context of agile production system. Sukati et al. (2014) examined the relationships between information technology practices (ITP) and supply chain agility (SCA) and reported that organization should consider ITP that can improve SCA. Talib and Rahman (2012) reported that to ensure successful implementation of total quality management (TQM) in the banks, there are essential dimensions which have to be addressed such as management commitment and support towards TQM, motivating and training of employees, and monitoring of customers' requirement through feedback. Taleghani et al. (2014) analyzed the effects of flexibility, competence of employees, empowerment and job security on making the organizations agile.

Torkiyan et al. (2014) determined the relationship between using information technology and organizational agility in youth sports organizations of Isfahan province. With the expansion of internet, delivering e-services have been grown in banking industry, significantly, improving e-service quality for delivering better services is an essential task of activity for banks. Yaghubi and Seyedin (2015) identified 8 major dimensions influencing on banking industry including security with a score, technical sufficiency, reliability. 


\section{The proposed study}

This paper presents an empirical investigation to identify the priority of factors affecting the quality of banking services in emerging export banks for better allocation of resources to enhance the quality of the banking services. The study develops a fuzzy method to handle uncertainty associated with the data and using analytical network process (Saaty, 2006) ranks different factors influencing on service quality. Fig. 1 demonstrates the hiarachy of the factors and their relationships gathered from experts.

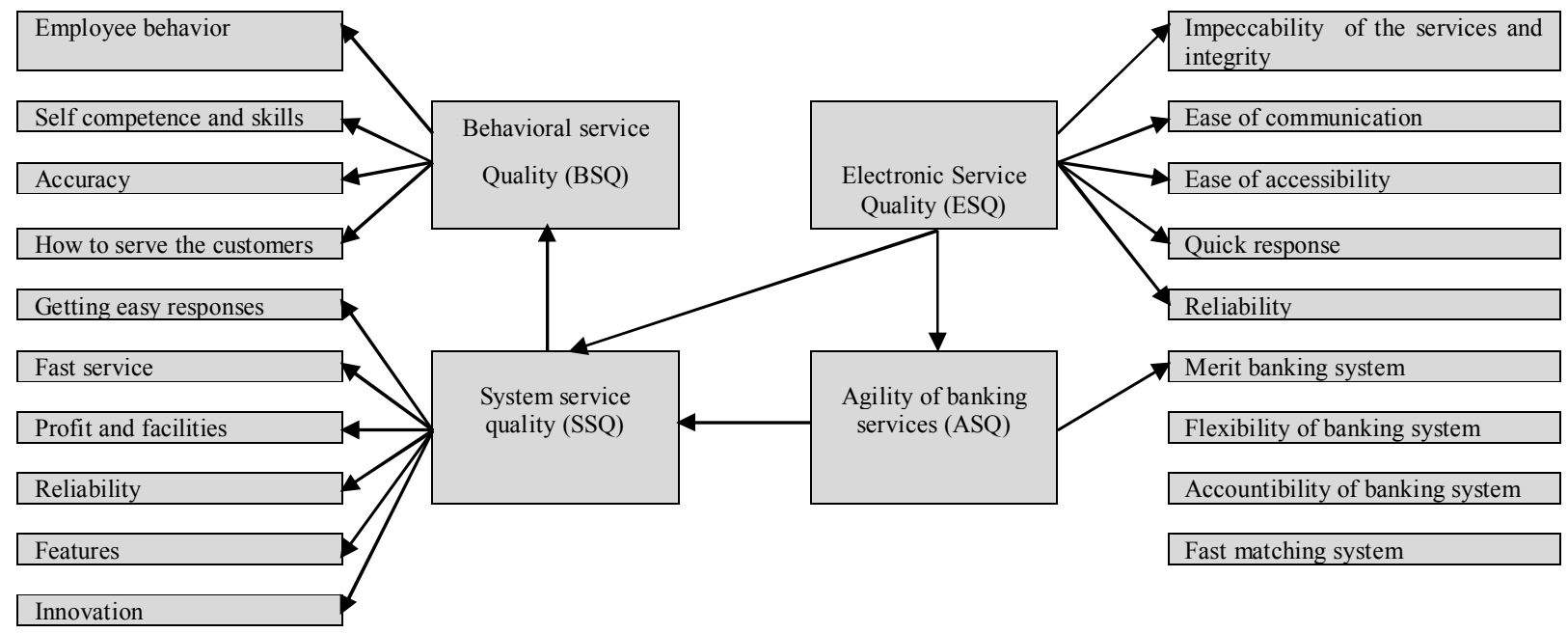

Fig. 1. Overall design of research model: Proposed criteria and sub-criteria affecting the quality of banking services

The method of this research is based on data collection, correlation, and the target is within the framework of applied research. Data collection tools, questionnaires, the population consists of banking experts and academic professionals who have expertises and experiences in the field of banking services. Of this population, 33 banking experts and academic professionals, both in retail banking and familiar with organizational agility were chosen. The study uses Analytic Network Process (ANP) (Saaty, 2006) for ranking different factors shown in Fig. 1. The proposed study uses a method earlier developed by Dağdeviren and Yüksel (2010) to prioritize the factors affecting the quality of banking services. To determine the weights of criteria and sub-criteria, a combination of mathematical model using triangular fuzzy numbers (Zadeh, 1997) is implemented. This model consists of seven steps which are described below (Dağdeviren \& Yüksel, 2010):

Step 1: Identify the criteria and sub-criteria used in the model

Step 2: Organize network model for hierarchical analysis process (aim, criteria, sub-criteria)

Step 3: Determine the initial weights of criteria and sub-criteria using pairwise comparison matrices (assuming independence criteria) using the following model:

$\max \alpha$

subject to

$\left(m_{i j}-l_{i j}\right) \alpha w_{j}-w_{i}+l_{i j} w_{j} \leq 0$

$\left(u_{i j}-m_{i j}\right) \alpha w_{j}+w_{i}-u_{i j} w_{j} \leq 0$

$\sum_{k=1}^{n} w_{k}=1, w_{k}>0, i=1, \cdots, n-1, j=1, \cdots, n j>i$ 
Here $w$ represents the weight for each criteria, $l_{i j}, m_{i j}$ and $u_{i j}$ are associated with a triangular fuzzy numbers (Dağdeviren \& Yüksel, 2010).

Step 4: Determine the interations between each pair of criteria with the help of experts and multiply the resulted matrix weights obtained from the third step

Step 5: Calculated the weights of the final sub-criteria by multiplying the sub-criteria weights obtained in third step in the final weight criteria calculated in Step 4

Step 6 : Use language scales to calculate the weight of sub-criteria

Step 7: Calculate the final weights.

After collecting all the criteria affecting the quality of banking services through the former research literature, ranking factors that affect the quality of banking services agile, through Analytic Network Process, is performed as shown in Fig. 2. The criteria and sub-criteria for quality banking services include four criteria and 19 sub-criteria. The criteria used in this study include behavioral quality service providers (BSQ), Electronic Service Quality (ESQ), quality of service (SSQ) and agile banking service quality (ASQ).

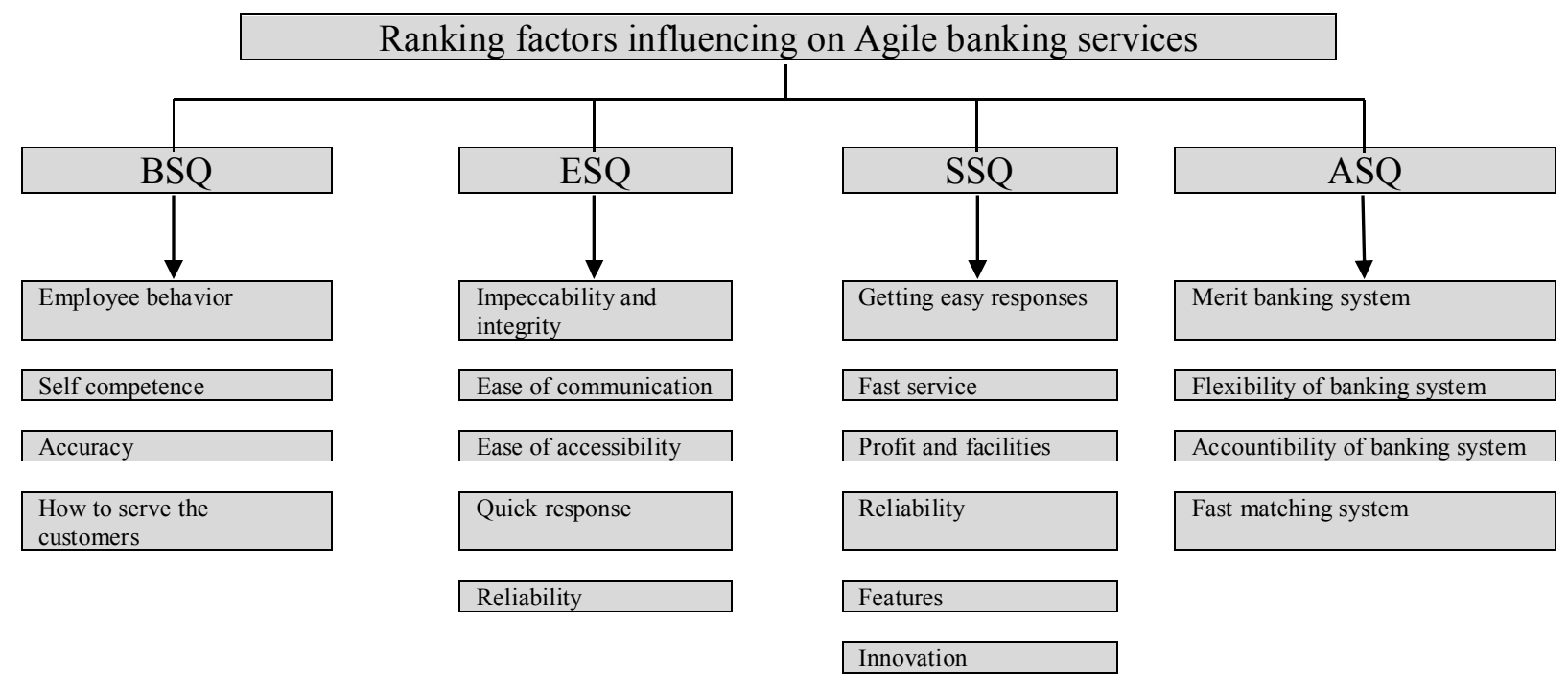

Fig. 2. The hierarchy of factors influencing on Agile banking service

The first step for the implementation of ANP method is to compare four criteria. Table 1 demonstrates the results of pairwise comparison. As we can observe, all comparisons are given in terms of triangular fuzzy numbers.

\section{Table 1}

The results of pairwise comparison

\begin{tabular}{ccccc}
\hline Factors & BSQ & ESQ & SSQ & ASQ \\
BSQ & $(1,1,1)$ & $(1.2,1,3.2)$ & $(1.2,2.3,1)$ & $(2.3,1,2)$ \\
ESQ & $(2.3,1,2)$ & $(1,1,1)$ & $(1.2,1,3.2)$ & $(2.3,1,2)$ \\
SSQ & $(1,3.2,2)$ & $(2.3,1,2)$ & $(1,1,1)$ & $(1,3.2,2)$ \\
ASQ & $(1.2,1,3.2)$ & $(1.2,1,3.2)$ & $(1.2,2.3,1)$ & $(1,1,1)$ \\
\hline
\end{tabular}

Here, the mathematical model given in Eq. (1) for the pairwise comparison of the four criteria of the research model has been used. The implementation has indicated that the objective function value of $\alpha$ is equal to 0.74 , which means the comparisons are fairly desirable. Weights from pairwise comparisons for Quality of behavior, electronic service quality, quality service and quality of banking services agile 
system are 23, 26, 30, and 21 percent, respectively. Next, the interplay criteria on each other with the use of experts can be seen in Table 2 .

Table 2

Matrix interactions of criteria on each other

\begin{tabular}{ccccc}
\hline Factors & BSQ & ESQ & SSQ & ASQ \\
\hline BSQ & 0.9 & 0 & 0 & 0 \\
ESQ & 0 & 1 & 0.1 & 0.1 \\
SSQ & 0.1 & 0 & 0.7 & 0 \\
ASQ & 0 & 0 & 0.2 & 0.9 \\
\hline
\end{tabular}

The numbers in Table 2 reflect the mutual effects criteria on each other. After that, the weights of the criteria and the sub-criteria are calculated and using linguistic variables, the weights are adjusted. There are two characteristic variables, severity and nature determined by experts, which may be either positive or negative. For example, if the intensity requires high standard and this standard will have a positive effect, a value of 0.75 is assigned. But if the impact is negative, the number assigned is 0.25 . The values of linguistic variables are based on the effectiveness criteria in Table 3.

Table 3

Values of linguistic variables based on effectiveness of criteria

\begin{tabular}{ccc}
\hline Negative effect & Positive effect & amount allocated \\
\hline Very low $(\mathrm{VL})$ & Very High $(\mathrm{VH})$ & 1 \\
Low $(\mathrm{L})$ & High $(\mathrm{H})$ & 0.75 \\
Medium $(\mathrm{M})$ & Medium $(\mathrm{M})$ & 0.5 \\
High $(\mathrm{H})$ & Low $(\mathrm{L})$ & 0.25 \\
Very High $(\mathrm{VH})$ & Very low $(\mathrm{VL})$ & 0 \\
\hline
\end{tabular}

Based on the linguistic numbers, the weights of the sub-criteria are determined, which are summarized in Table 4 as follows,

Table 4

Linguistic variables and weight of sub-criteria

\begin{tabular}{|c|c|c|c|c|}
\hline Under criteria & Under weighted criteria & linguistic variable & linguistic variable & Final weight \\
\hline$\overline{\mathrm{BSQ}_{1}}$ & 0.050 & $-\mathrm{L}$ & 0.75 & 0.037 \\
\hline $\mathrm{BSQ}_{2}$ & 0.071 & $\mathrm{VH}$ & 1 & 0.071 \\
\hline $\mathrm{BSQ}_{3}$ & 0.050 & M & 0.5 & 0.025 \\
\hline $\mathrm{BSQ}_{4}$ & 0.058 & $\mathrm{H}$ & 0.75 & 0.043 \\
\hline $\mathrm{ESQ}_{1}$ & 0.052 & $\mathrm{VH}$ & 1 & 0.052 \\
\hline $\mathrm{ESQ}_{2}$ & 0.052 & M & 0.5 & 0.026 \\
\hline $\mathrm{ESQ}_{3}$ & 0.052 & $\mathrm{H}$ & 0.75 & 0.039 \\
\hline $\mathrm{ESQ}_{4}$ & 0.044 & $-\mathrm{L}$ & 0.75 & 0.033 \\
\hline $\mathrm{ESQ}_{5}$ & 0.060 & VH & 1 & 0.060 \\
\hline $\mathrm{SSQ}_{1}$ & 0.045 & $\mathrm{H}$ & 0.75 & 0.034 \\
\hline $\mathrm{SSQ}_{2}$ & 0.045 & $\mathrm{M}$ & 0.5 & 0.022 \\
\hline $\mathrm{SSQ}_{3}$ & 0.051 & M & 0.5 & 0.025 \\
\hline $\mathrm{SSQ}_{4}$ & 0.057 & $\mathrm{VH}$ & 1 & 0.057 \\
\hline $\mathrm{SSQ}_{5}$ & 0.051 & $\mathrm{H}$ & 0.75 & 0.038 \\
\hline $\mathrm{SSQ}_{6}$ & 0.051 & $-\mathrm{M}$ & 0.5 & 0.025 \\
\hline $\mathrm{ASQ}_{1}$ & 0.057 & $-\mathrm{L}$ & 0.75 & 0.043 \\
\hline $\mathrm{ASQ}_{2}$ & 0.046 & M & 0.5 & 0.023 \\
\hline $\mathrm{ASQ}_{3}$ & 0.063 & $\mathrm{H}$ & 0.75 & 0.047 \\
\hline $\mathrm{ASQ}_{4}$ & 0.044 & M & 0.5 & 0.022 \\
\hline Total & & & & 0.722 \\
\hline
\end{tabular}

We also consinder the information of Table 5 to make possible decisions. Final weights of the main criteria affecting the quality of banking services are as follows: Quality of electronic services (weight: 
0.31 ), the quality of banking services agility (weight 0.25 ), quality of service (weight 0.23 ) and behavioral qualities (weight 0.21 ).

Table 5

The basis of final decision

\begin{tabular}{cc}
\hline value obtained & Level quality banking services \\
\hline $0.8<X<1$ & Very high \\
$0.6<X<0.8$ & high \\
$0.4<X<0.6$ & Medium \\
$0<X<0.4$ & Low \\
\hline
\end{tabular}

The final ranking of sub criteria affecting the assessment of the quality of banking services are summarized in Table 6.

Table 6

Final Rank of sub-criteria affecting the assessment of the quality of banking services

\begin{tabular}{clc}
\hline Sub-Criteria Code & Sub-Criteria & Final weight \\
\hline $\mathrm{BSQ}_{2}$ & Staff competence and skills & 0.071 \\
$\mathrm{ESQ}_{5}$ & Reliability (electronic systems) & 0.060 \\
$\mathrm{SSQ}_{4}$ & Reliability (service system) & 0.057 \\
$\mathrm{ESQ}_{1}$ & Impeccability and integrity of devices & 0.052 \\
$\mathrm{ASQ}_{3}$ & Accountability of banking system & 0.047 \\
$\mathrm{BSQ}_{4}$ & Accountability & 0.043 \\
$\mathrm{ASQ}_{1}$ & Merit banking system & 0.043 \\
$\mathrm{ESQ}_{3}$ & Ease of access & 0.039 \\
$\mathrm{SSQ}_{5}$ & Physical Features & 0.038 \\
$\mathrm{BSQ}_{1}$ & Employee behavior & 0.037 \\
$\mathrm{SSQ}_{1}$ & Easy to get services & 0.034 \\
$\mathrm{ESQ}_{4}$ & Responsiveness & 0.033 \\
$\mathrm{ESQ}_{2}$ & Ease of communication & 0.026 \\
$\mathrm{BSQ}_{3}$ & staff Accuracy & 0.025 \\
$\mathrm{SSQ}_{3}$ & Profit and facilities & 0.025 \\
$\mathrm{SSQ}_{6}$ & creativity & 0.025 \\
$\mathrm{ASQ}_{2}$ & Flexibility of banking system & 0.023 \\
$\mathrm{SSQ}_{2}$ & Responsiveness to customers & 0.022 \\
$\mathrm{ASQ}_{4}$ & Speed matching of banking system & 0.022 \\
\hline
\end{tabular}

\section{Conclusion}

In this paper, we have presented an empirical investigation to determine factors influencing the quality of banking services in Bank Saderat Iran for better allocation of resources to enhance the quality of its banking services. The study has developed a fuzzy method to handle uncertainty associated with the data and using analytical network process ranked various factors affecting the service quality. The results have indicated that the quality of e-services has been the most important factor followed by the quality of banking services agility, the quality of service, and the behavioral qualities. Moreover, the employees' competence and skills, the reliability of the electronic system and the reliability of the service system, an impeccability banking system integrity and accountability instruments were among other effective factors influencing on the quality of banking services. The results are consistent with findings of Jassbi et al. (2014) and Landaran et al. (2014) in terms of service agility. The results are also in line with findinds of Kaur and Kiran (2015) in terms of reaching better customer satisfaction by enhancing different features. Mediavilla Saldaña et al. (2014) also reported similar results. Yaghubi and Seyedin (2015) also used analytical hierarchy process for ranking the technical dimensions of ebanking service quality evaluation models and reported somewhat similar factors influencing the most on e-bussiness. 


\section{Acknowledgement}

The authors would like to thank the officials of Bank Saderat Iran for cordially supporting this project. We are also delighted for constructive comments on earlier version of this paper.

\section{References}

Aneesh A., Dileeplal J., \& Abraham M., (2014)., An integrated fuzzy weighted Servqual-QFD approach for service quality improvement. International Journal of Engineering Research, 3(12), 774-776.

Cheserek, L. K., Kimwolo, A. K., \& Cherop, F. (2015). Effect of quality financial services on customer satisfaction by commercial banks in Kenya. International Journal of Humanities and Social Science, 5(7), 102-112.

Dağdeviren, M., \& Yüksel, İ. (2010). A fuzzy analytic network process (ANP) model for measurement of the sectoral competititon level (SCL). Expert Systems with Applications, 37(2), 1005-1014.

Dehaghi, A. K., Navabakhsh, M., \& Ardestani, H. R. A. (2014). Study the effect of individual factors to implementing the agility strategy in Isfahan municipality. International Journal of Academic Research in Economics and Management Sciences, 3(1), 61-74.

Gunarathne, U. (2014). Relationship between service quality and customer satisfaction in Sri Lankan hotel industry. International Journal of Scientific and Research Publications, 4(11), 1-7.

Igaz, A. T., \& Ali, A. (2013). Measuring banks service attitude: An approach to employee and customer acuities. Journal of Business and Management, 7(2), 60-66.

Jahanshani, A. A., Hajizadeh, G. M. A., Mirdhamadi, S. A., Nawaser, K., \& Khaksar, S. M. S. (2014). Study the effects of customer service and product quality on customer satisfaction and loyalty. International Journal of Humanities and Social Science, 1(7), 253-260.

Jassbi, J., Pilevari, N., \& Garmaki, M. (2014). Role of time in agile supply chain. International Journal of Industrial Engineering, 25(2), 115-124.

Kaur N., \& Kiran R. (2015). E-banking service quality and customer loyalty: Changing dynamics of public, private and foreign bank consumers in India. Global Business and Management Research: An International Journal, 7(1), 74-92.

Kazemi, M., \& Amini, A. (2013). Identify and ranking factors affecting bank maskan service quality using Kano model. Research Journal of Recent Sciences, 2(4), 11-19.

Landaran, S., Forghani, M. H., Hamidi, V., \& Dehaghi, M. R. (2014). Studying the relationship between organizational learning \& dimension of organizational agility: a case studi-university of Isfahan. Journal of social issues \& humanities, 2(2), 146-151.

Mediavilla Saldaña, L., Gómez Encinas, V. F., \& Sánchez Burón, A. (2014). The technical quality of the service provided by adventure companies in Spain, Italy and Costa Rica. Journal of Human Sport and Exercise, 9(1), 157-171.

Munir, M.M.M., \& Rahman, M. (2015). E-banking service quality and customer satisfaction of a state owned schedule bank of Bangladesh. Journal of Internet Banking and Commerce, 2(9), 1-5.

Nikzat, P., Rezazadeh, B., \& Bashir Khodaparasti, R. (2014). Linking the three dimensional service quality model to customer satisfaction and loyalty. International Journal of Management and Humanity Sciences. 3(12), 3819-3831.

Prasad, R. K., \& Kumar Jha, M. (2013). Quality measures in higher education: A review and conceptual model. Quest Journals, Journal of Research in Business and Management, 1(3), 23-40.

Phan, C. A., \& Nham, P. T. (2015). Impact of service quality on customer satisfaction of automated teller machine service: case study of a private commercial joint stock bank in Vietnam. Business: Theory and Practice/Verslas: Teorija ir Praktika, 16(3), 280-289. 
Porkiani, M., \& Hejinipoor, M. (2013). Studying the relationship between organizational intelligence and organizational agility in supreme audit court. European Online Journal of Natural and Social Sciences, 2(3), 1052.

Pourhasomi, M., Khamseh, A., \& Ghorbanzad, Y. (2013). A hybrid of Kano and QFD for ranking customers' preferences: A case study of bank Melli Iran. Management Science Letters, 3(3), 845860.

Van Quyet, T., Vinh, N. Q., \& Chang, T. (2015). Service Quality Effects on Customer Satisfaction in Banking Industry. International Journal of u-and e-Service, Science and Technology, 8(8), 199206.

Rostami, A., Khani, A. H. A., \& Soltani, G. (2016). The impact of e-service quality on the improvement of the level of communication with customers of bank Melli branches in south Tehran affairs office. Procedia Economics and Finance, 36, 448-455.

Parasuraman, A., Zeithaml, V. A., \& Berry, L. L. (1988). Servqual. Journal of retailing, 64(1), 12-40. Saaty, T. L. (2006). The Analytic Network Process (pp. 1-26). Springer US.

Sakhaei, F., Afshari, A., \& Esmaili, E. (2014). The impact of service quality on customer satisfaction in Internet banking. Journal of Mathematics and Computer Science, 9, 33-40.

Sanadgol, M. (2014). The survey of relationship between organizational agility and principals job satisfaction. International Journal of Basic Sciences \& Applied Research, 3, 317-319.

Sazesh, A., \& Siadat S. A. (2015). The relationship between quantum management and organizational agility in ministry of roads and urban development of Golestan province, Iran. International Research Journal of Management Sciences, 3, 28-31.

Seyedhosseini, S., \& Keyghobadi, A. (2014). An integrated model for mechatronic products in agile manufacturing system. Decision Science Letters, 3(4), 535-550.

Shaarabh, M., Rishi, G., Sharma, S.K. (2014). A review on measurement of agility. Industrial Engineering \& Management, 3(1), 1-4.

Sureshchandar, G. S., Rajendran, C., \& Anantharaman, R. N. (2002). Determinants of customerperceived service quality: a confirmatory factor analysis approach. Journal of Services Marketing, 16(1), 9-34.

Sukati, I., Hamid, A.B., Baharun, R., \& Mohammad Jamal, N. (2014). The moderating role of market, firm and supply chain factors on the relationship between information technology practices and supply chain agility. American Journal of Industrial and Business Management, 4, 258-266.

Talib, F., \& Rahman, Z. (2012). Impact of total quality management and service quality in the banking sector. Journal of Telecommunications System \& Management, 1(2), 1-5.

Taleghani, G. R., Amirkhani, A. H., \& Froughi, H. (2014). Identify and prioritize the factors affecting the implementation of agile manufacturing (Case Study: Khui Sugar Factory). Journal of Novel Applied Sciences, 3(10), 1122-1124.

Torkiyan, K., Khorvash, M., \& Tabaeiyan, A. (2014). On the relationship of applying information technology with organizational agility in youth aports organizations of Esfahan province. International Journal of Sport Studies, 4(12), 1546-1550.

Yaghubi, N., \& Seyedin, S. M. (2015). Ranking the technical dimensions of e-banking service quality evaluation models using Analytical Hierarchy Process. Advances in Computer Science: an International Journal, 4(1), 37-43.

Zadeh, L. A. (1997). Toward a theory of fuzzy information granulation and its centrality in human reasoning and fuzzy logic. Fuzzy Sets and Systems,90(2), 111-127. 